\title{
RACISMO ESTRUTURAL E O PARADIGMA ANTINEGRO: O PROIBICIONISMO E A GUERRA ÀS DROGAS COMO OS NOVOS GRILHÕES DOS NEGROS BRASILEIROS*
}

\author{
Ana Paula Procópio da Silva \\ Joílson Santana Marques Júnior
}

\section{Introdução}

Neste capítulo nos dedicamos a uma breve reflexão sobre racismo estrutural e a antinegritude e/ou racismo antinegro ${ }^{1}$ como razão encoberta da criminalização das populações negras, e da chamada guerra às drogas ${ }^{2}$. Apontando como historicamente o negro tornase lócus de intervenção jurídico-policial, o que acabou por refletir-se na constituição da legislação que estabeleceu a cisão entre as figuras de usuário e traficante.

A historicização apresentada problematiza como os elementos do pensamento ocidental europeu que criaram a lógica escravocrata continuam produzindo a subjetivação do negro como não ser, como um lugar/imagem repositório da desqualificação, da suspeita, da criminalização e por fim da escolha punitiva pela morte.

\footnotetext{
"DOI- 10.29388/978-65-86678-44-4-0-f.185-284

${ }^{1}$ Evidentemente a questão da antinegritude e a questão do racismo antinegro não se reduzem a mesma, para nós trata-se de dois processos diferentes, inter-relacionados, cujo o primeiro é marcado muito mais pela construção do que é ser negro como polo negativo da modernidade, enquanto o segundo dialoga com os processos derivados da constituição da raça como um conceito primeiro biológico/social e após a queda do caris biológico, sua continuidade através do racismo enquanto sistema que hierarquiza a diversidade humana.

${ }^{2}$ No decorrer do texto recorremos ao termo droga, por sua carga simbólica e material, uma vez que, por exemplo, não se trata de guerra aos psicoativos, algo que por si já expõe a seletividade no chamado discurso antidroga, quando se fizer necessário, tanto em respeito a autores, como a própria forma de travar o debate proposto, utilizaremos os termos psicoativos, entorpecentes etc.
} 
Um arcabouço estrutural que tornou os sujeitos negros menos passiveis do cuidado em saúde, incluindo a saúde mental, ao mesmo tempo em que os elegeu como o alvo preferencial das ditas políticas de segurança pública, comumente materializadas em incursões violentas contra comunidades periféricas.

Embora nossas reflexões tratem especificamente das condições estruturais e da situação brasileira, recorreremos, por vezes a eventos internacionais, porém, não traçaremos aqui o significado dessa guerra para as populações negras no mundo. Do mesmo modo, não abordaremos, como os povos indígenas são afetados, porque nossa demarcação reflexiva centra-se na forma como o desenho de uma determinada política foi traçado a partir das relações históricas do Estado brasileiro com as populações negras.

Como intelectuais negros, optamos metodologicamente por utilizar uma cena real como disparador para trazer à baila as reflexões das questões apontadas. Um dado de realidade concreta que expõe o racismo estrutural e a questão da antinegritude, e cuja materialidade dada na criminalização e na guerra às drogas que tem como resultantes, o encarceramento e a morte: os novos grilhões dos negros brasileiros.

Estou parado aguardando por um atendimento, entram dois policiais civis com fuzis em punho, com dois adolescentes, com aparência de talvez quatorze anos, são negros, estão descalços, sem camisa, estão algemados e molhados [talvez suor] e são conduzidos pela porta da frente da delegacia. Quando atravessam o balcão de atendimento e adentram o espaço reservado aos profissionais que ali trabalham, um dos policiais grita em tom extremamente autoritário "abaixem a cabeça!" e o outro diz: "vocês já conhecem o caminho". As pessoas que estão como eu, à espera de atendimento, começam a falar: "tudo marginal, bandidinhos...". Poucos minutos depois um dos policiais começa a contar na nossa frente a prova do crime, alguns poucos papelotes de cocaína..." (Cena real ocorrida em uma delegacia da Baixada Fluminense, no ano de 2017)

Um elo dos grilhões em que as populações negras são mantidas aprisionadas e que foi observado na cena é que as pessoas que estavam naquela delegacia aguardando atendimento, e corroboraram com a apreensão, eram da mesma origem racial daqueles jovens, 
mas não se viam neles, não conseguiam pensar, inclusive, que podia ser um filho, um sobrinho, um neto.

Eles já estavam, além de presos, condenados, na verdade secretamente sentenciados, até mesmo pelos "seus". A questão aqui é compreender o que constitui essa forma de subjetivação e que legitima o não estranhamento da maioria das pessoas com a cena. $O$ que encobre a ausência do olhar crítico sobre o ocorrido? O que torna tão natural que algumas daquelas pessoas falassem até em execução como punição para aqueles jovens? Por que a relação direta entre a apreensão de jovens negros com uma determinada quantidade de drogas e tráfico e não com uso? Por que a construção de uma lógica de guerra às drogas e do discurso das drogas como caos social?

É importante lembrar da tautologia presente no termo "guerra às drogas". A guerra ocorre sobre o lema da defesa do bem-estar social, prometendo que as prisões e as mortes dos traficantes, supostamente, garantirão a paz e a saúde pública. Pessoas são lançadas no sistema prisional, encarceradas para o bem da coletividade. O amálgama entre a discussão científica do malefício das drogas e a ilicitude, ou seja, a construção entrelaçada dos discursos da saúde e da segurança pública torna o lema guerra às drogas uma explicação em si mesmo (HENMAM, 1983).

Não que o uso de substâncias químicas de diferentes tipos, não causem impactos para a saúde, contudo, a escolha de quais substâncias serão institucionalizadas pelo Estado como lícitas e ilícitas, passa não somente pelo crivo do poder biomédico, mas sobretudo, pelos interesses econômicos ${ }^{3}$.

\begin{abstract}
O uso de uma justificativa médica e de saúde pública para se proibir certas drogas é contraditório com o fato de que algumas das substâncias mais perigosas são permitidas devido ao seu uso ser tradicional no Ocidente cristão. O cigarro, por exemplo, desde a guerra da Criméia incorporou-se à ração dos exércitos e aos hábitos populares, o chá e o ópio à dieta da Inglaterra vitoriana, e o álcool na forma do vi-
\end{abstract}

\footnotetext{
${ }^{3}$ A maconha é um bom exemplo, pois seus subprodutos, principalmente sua fibra era reconhecida desde séculos anteriores como sendo de boa qualidade para a produção de tecidos, porém, a indústria têxtil do algodão foi uma das financiadoras das campanhas de proibição da planta, demonstrando que o jogo entre o proibido e o permitido pelo Estado não foge à lógica da disputa comercial (HENMAM, 1983; FERRUGEM, 2019; LUNARDON, 2015).
} 
nho, da cerveja e dos destilados continua sendo a bebida nacional de muitas nações (CARNEIRO, 2002, p. 119).

\section{O Negro é a droga contra o qual se propõe a guerra}

"Não temos um genocídio, seguimos com um genocídio" (FERRUGEM, 2019, p. 89). A assertiva da autora nos faz retomar a cena da Introdução deste ensaio, uma vez que toda ela nos lança ao tempoespaço da escravidão: os corpos negros, a violência sem limites, o lugar de encarceramento, os agentes da segurança, a exposição pública.

A cena reproduz e visibiliza algo para além do que mostra de imediato, que a criminalização, o encarceramento e o genocídio da população negra não são recentes, têm suas raízes num sistema de escravidão que é reatualizado, em múltiplas e complexas determinações e revivido cotidianamente no tempo presente.

Ao mesmo tempo a cena mostra onde está inscrito o lugar do negro: o socialmente perigoso. Uma inscrição que está na pele, na marca de cor que justificou a escravidão negra como a condenação por uma culpa bíblica que só poderia ser expiada servindo a vida inteira como escravizado, em virtude de sua origem pecaminosa criada a partir do mito de Cam ${ }^{4}$ (BORGES, MEDEIROS \& D'ADESKY, 2002).

A própria diáspora negra é marcada pelo ato dos sujeitos serem arrancados de sua Terra ${ }^{5}$, de ter sido tentado, desde então, retirar-Ihes a possibilidade de se nomear, de contar sua história, de ter reconhecido a sua genealogia, pela massificação e indiferenciação que marcam esse processo (VARGAS, 2019; MBEMBE, 2018).

Nas Américas, a colonização e a escravidão assentam-se na hierarquização das diferenças entre conquistadores e conquistados. A

\footnotetext{
${ }^{4}$ A difusão da África como lócus do pecado tem origem no mito bíblico de Cam e foi utilizado como justificativa moral e ideológica da escravidão negra. O mito estabelece a pele escura como um estigma, a marca de Cam, que simboliza a punição do filho que viu a nudez de Moisés, seu pai. E essa marca estendeu-se também à compreensão, inclusive dos lugares habitados por negros, sendo o calor dos territórios africanos entendido como um símbolo da sua condenação ao inferno (OLIVA, 2017; CARNEIRO, 2005).

${ }^{5}$ Usamos Terra com letra maiúscula como símbolo de mundo, permitindo-nos parafrasear Dussel (1993) em sua concepção de que para os povos originários o "descobrimento" significou o fim de um mundo, para os Africanos escravizados aquele era o fim de um mundo.
} 
ideia de raça, coloca todos em seus "lugares", situa os nativos da terra e os africanos escravizados em condição "natural" de inferioridade em relação aos europeus. Este é o mito fundacional das relações coloniais de dominação, que posteriormente foi cristalizado numa formatação ideológica que se mantem mesmo com as independências das colônias.

Deste modo a colonialidade do poder (QUIJANO, 2005) funciona como ideologia de perpetuação do domínio das antigas metrópoles, mantendo um sistema de teorias e práticas sociais que justificam relações de opressão e exploração entre territórios geograficamente distantes. Os territórios colonizados foram alvo de um projeto de universalização dos ideais civilizatórios europeus que estabeleceram como verdade uma suposta superioridade ocidental como padrão de desenvolvimento para os povos dominados. Esse movimento de levar "civilização" aos "primitivos" redundou em processos de destruição, assassinatos em massa e espoliação sem precedentes

A violência da escravidão moderna enquanto estrutura político-jurídica fundamenta e institucionaliza de forma irreversível a expulsão dos negros da proposta de humanidade liberal. Em contrapartida, o sistema de dominação construído ultrapassa os estatutos legais e a exploração da escravidão, pela contínua tentativa de destruição dos espíritos e da própria humanidade dos sujeitos escravizados. Por isso, a sujeição à língua dos conquistadores era tão importante no processo colonizador, afinal a língua é uma maneira de formular e expressar o pensamento e de transmitir o conhecimento sobre o mundo.

Assim, negro também é definido pelas negativas, como aquele que não é o "conquistador", não é o "originário", não é o "imigrante", mas é aquele que contra a sua vontade foi sequestrado, traficado, acorrentado e exposto para apreciação pública de seu corpo e sua dor, configurando uma condição possivelmente única na modernidade.

O corpo negro tornou-se aquele que deveria ser recorrentemente posto no lugar da inferioridade, um corpo que mais do que domesticado, deveria servir como instrumento para a satisfação de outrem, aprendendo a não ser digno nem mesmo de possuir o seu próprio corpo. Um corpo que como aponta Vargas (2017) é constituí- 
do como alvo da violência gratuita, já que ser negro é não ser e há sempre a suspeita inaudita de que somos algo que não pode ser totalmente reconhecido.

A escravidão moderna fundou uma nova lógica sobre a própria ideia de escravidão, pois transformou uma condição em algo instituinte do ser, tornando negro e escravo como sinônimos. Uma construção anterior ao racismo científico do século XIX, que estabeleceu o negro como aquele que não era, não era racional, não era belo, não era inocente e, por fim, não era (é) humano (CARNEIRO, 2005).

Logo, entendemos que o paradigma fundante do ser negro foi construído nos processos de escravização ${ }^{6}$ e de colonialismo, e nos diálogos com Carneiro (2005), Mbembe (2018) e Kilomba (2020), Fanon (2008) podemos então compreender o negro como um lugar e como uma existência-repositório de tudo que é pensado e sentido como negativo em termos de humanidade. Foi usando o negro como reflexo distorcido de si mesmo que o europeu atribuiu a este os seus próprios "pecados": a violência do sequestro, o estupro, a pilhagem das terras. E caracterizou para si esses feitos como conquista, descoberta, exploração, expansão civilizatória, desenvolvimento etc. Os europeus invasores são louvados como heróis colonizadores, enquanto as populações originárias são exterminadas e/ou tuteladas e os negros demonizados.

Por outro lado, a condição social de escravo expõe a contradição estrutural do sistema: a cisão entre a liberdade de propriedade e a liberdade da pessoa. Isso porque os sujeitos escravizados sempre mantiveram a sua capacidade humana real de desenvolver pontos de vista diferentes sobre o tempo, o trabalho e sobre si, mesmo no horror da escravidão.

Tratado como se não existisse, exceto como mera ferramenta e instrumento de produção, o escravo, apesar disso, é capaz de extrair de quase qualquer objeto, instrumento, linguagem ou gesto uma representação e estilizá-la. Rompendo com sua condição de expatriado e com o puro mundo das coisas do qual ele ou ela nada mais é do que um fragmento, o escravo é capaz de demonstrar as capacidades poli-

\footnotetext{
${ }^{6}$ A escravização negra, enquanto processo histórico, antecede ao colonialismo como sistema, mas não podemos separá-los hermeticamente, já que uma das "mercadorias" mais rentáveis no colonialismo foi o próprio negro (DUSSEL, 1993).
} 
morfas das relações humanas por meio da música e do próprio corpo que supostamente pertencia a um outro (MBEMBE, 2018, p. 30).

A criminalização das populações negras está também arraigada ao cerne do direito moderno e as relações privadas de propriedade. Se considerarmos que a forma como o proprietário trata sua relação com a propriedade é um reflexo de como se estabelecem as relações sociais dentro de um grupo, supomos que para proprietários de pessoas que tinham pouco ou nenhum limite em relação ao "objeto" de sua propriedade, essa relação moldou tanto o negro como bode expiatório quanto liberou o senhor de todos os pecados que cometesse.

Afirmamos então, que não existe racismo sem escravidão. 0 racismo é uma resultante dos processos de desumanização, escravização e genocídio de indígenas e negros, uma primeira culminância da longa gestação que pariu a naturalização das violências contra esses segmentos.

A construção da ideia de raça, como conceito materializou uma escala já colocada anteriormente, que começou a ser desenhada no século XVII em artigo publicado em 1684 por François Bernie que atribuiu comparações entre povos não europeus e alguns traços físicos de animais. E foi também nesse ensaio que o autor apresentou uma divisão dos humanos por raça ou espécie. No mesmo rastro $\mathrm{Ca}$ rolus Linnaeus, um botânico, em 1767 publicou um texto em que escalonou os grupos humanos atribuindo-Ihes características determinadas, delegando ao homem europeu um rol de positividades e aos africanos o lugar mais baixo na escala. Contudo, deve-se a Georges Curvier, naturalista, a definição de raças humanas e a cunhagem científica do termo articulando fenótipos, herança genética, cultura e caráter (Borges et.al., 2002; SCHWARZ,1993). Assim, as relações sociais derivadas e globalmente espraiadas conformam em termos mundiais uma hierarquização racial. Neste sentido, raça remete ao racismo estrutural, à escravidão, mas também às imagens construídas sobre "ser negro", "ser indígena" e "ser branco".

A raça, portanto, não é uma ideia que vem de fora e cai sobre a cabeça de intelectuais do século XIX no Brasil. A sua própria estruturação deve-se a criação anterior de uma hierarquia racial onde os 
brancos se encontram no ponto superior e sua imagem representa a própria humanidade e os negros estão no oposto inferior, distantes da representação humana.

Esta escala, entendida como branquitude organiza um sistema tanto classificatório quanto hierárquico, no qual o valor da vida adquire um sentido particular, pois independente do que um negro realize, este ato não será valorado nos mesmos termos que o ato de um branco. A menos valia da vida negra tem como parâmetro o mais valor da vida branca. Um fio condutor que nos auxilia a desnaturalizar os dados divulgados todos os dias e que mostram a extrema desigualdade entre negros e brancos construída no país, particularmente, a partir do pós-abolição.

A abolição colocou para o Estado, como pauta prioritária, a questão sobre o destino negro do Brasil republicano, porque aqueles que foram as mãos e pés do senhor, viraram um problema nacional, convertidos nos culpados pelo atraso em relação aos países europeus.

As populações negras brasileiras nunca foram uma minoria quantitativa e sempre deram provas de suas rebeldias através de quilombos, insurreições e diversos outros tipos de contestações ao regime de dominação (MOURA, 1988).

No pós-abolição o racismo foi adequando seu poder de controle e punição sobre uma população majoritariamente negra. E foi nesse contexto a institucionalização da criminalização das práticas culturais negras, sem, contudo, recorrer a utilização do marcador racial na própria legislação, uma estratégia sofisticada que atinge o alvo, sem acionar o conflito direto.

Por este ângulo, entendemos que a criminalização de suas práticas socioculturais, como as religiões de matrizes africanas, a capoeira e o samba evidencia a construção de uma política de Estado que tem como objetivo a contenção através do encarceramento, mas também ao torna-las proscritas, demonstra o desejo de fazer desaparecer os seus sujeitos (BORGES 2018; LUNARDON, 2015).

Do mesmo modo, a gênese do proibicionismo é parte deste escopo, uma vez que, por exemplo, a prática de fumar maconha foi sendo associada aos negros porque tanto a planta como sua utilização foram entronizadas por africanos de Angola, no Brasil, fazendo 
parte da sociabilidade de alguns grupos negros e integrando alguns rituais religiosos (LUNARDON, 2015; HENMAN, 1983; FERRUGEM, 2018).

Em 1921 foi promulgada uma legislação que punia a venda de cocaína e opiláceos, que na prática foi estendida a maconha, porém foi em 1932 que a erva se tornou efetivamente uma substância ilícita. O desdobramento da progressiva legislação de controle/punição para negros tomou forma com a instauração da Delegacia de Costumes, Tóxicos e Mistificações (DCTM) em 1934, o que expressou também a articulação de diferentes dimensões das práticas socioculturais e da vida negra ao crime (LUNARDON, 2015; SAAD, 2018).

Por outro lado, um conjunto de Leis, criadas no imediato pósabolição, voltadas para os costumes, como a coibição da vadiagem, foi amplamente utilizada, na mesma lógica. Nesta acepção, o racismo basicamente funcionou como um mecanismo de encarceramento, particularmente em áreas urbanas, uma vez que o projeto de branqueamento da nação operacionalizado pela massiva entrada de imigrantes, expulsou os negros do mercado forma e facilitou o seu enquadramento e tipificação como vadios (ANDREWS,1998).

Assim, o racismo estrutural como uma forma social polimórfica está materializado em todas as dimensões da vida social e sua condição estruturante nas sociedades pós-coloniais o caracteriza como um componente dinâmico e com um significado mais abrangente na ideologia de dominação porque está entrelaçado a outros elementos de exploração e opressão.

\section{A realização de um fetiche: guerra às drogas, morte aos negros}

No fundo, não se procura solucionar um problema de saúde pública, e sim assegurar a representação de uma "verdade" científica, monolítica e intolerante, que ao mesmo tempo reflete e justifica o autoritarismo da estrutura política no plano maior (HENMAM,1983, p. 45).

O termo guerra às drogas tem sua origem comumente referida a campanha, liderada pelos Estados Unidos, de proibição de drogas, com a participação militar justificada pelo intuito de combater o 
comércio ilegal. A iniciativa estadunidense incluiu um conjunto de políticas de narcóticos destinadas à redução da produção, distribuição e o consumo das chamadas drogas psicoativas ilegais. A insígnia foi popularizada pela mídia logo após uma coletiva de imprensa em 18 de junho de 1971 pelo então presidente Richard Nixon, durante a qual ele declarou que o abuso do uso de drogas ilegais era o "inimigo público número um" da América. (LEMOS, 2015)

Esse processo, que ocorre em meio à crise econômica e a crise política do bloco comunista, permite aos Estados Unidos direcionar sua produção bélica para um novo inimigo, as drogas ${ }^{7}$ e espraiar a sua concepção internacionalmente. A repressão militarizada e o discurso antidrogas tornaram-se a forma, inclusive, como a Organização das Nações Unidas (ONU) passou a direcionar a relação com o tema ${ }^{8}$.

A retórica bélica construiu nos foros internacionais novos aportes ao imperialismo norte-americano calcado em intervenções militares e paramilitares em outros países, que passou a contar mais fortemente com a anuência dos órgãos internacionais. A guerra às drogas constituiu-se em uma nova forma de garantir poder estadunidense, sob a bandeira da defesa de uma sociedade livre das drogas (RODRIGUES, 2002).

No Brasil foi nos anos 1980 que tomou corpo a ideia de combater o uso de substâncias proibidas por lei através de uma guerra, consolidando sua agenda em acordo com o "Norte", uma vez que estamos na esteira do processo estadunidense.

A criação da Secretária Nacional Antidrogas - SENAD (1998) em meio a internalização da guerra às drogas, tornada uma pauta continental, diz não só do seu compromisso, mas do quanto esse lema tornou-se também prático para efeitos de manutenção de po-

\footnotetext{
${ }^{7}$ O proibicionismo como política nos Estados Unidos remonta ao período conhecido como Lei seca (1919), que proibiu o consumo de álcool no país. Uma política de cunho conservador com base religiosa que torna o álcool uma droga criminalizável, tendo como resultado a intensificação do mercado clandestino e um potencial aumento do uso, em suma o proibicionismo já nasceu como, fracasso no que se refere a diminuição de consumo de qualquer tipo de substancia (LEMOS, 2015; CARNEIRO, 2002; LUNARDON, 2015)

${ }^{8}$ Remontando há uma estratégia semelhante adotada na década de 1910 em relação a utilização da convenção das nações para impulsionar as medidas proibicionistas internas, o governo norte-americano nos anos 70 espraia seu discurso antidrogas, como pauta central na condução da questão e é acompanhado hegemonicamente pelos países que ratificam tratados de combate as drogas (FERRUGEM, 2019; LEMOS, 2015; RODRIGUES, 2002).
} 
der e de mais uns lócus de classificação do negro, agora como o traficante.

Cabe destaque o fato da pasta e suas funções terem sido remetidas para o controle das forças armadas. Em um país recém-saído da ditadura, um tema de saúde pública e liberdades dos indivíduos foi naturalizada a justificativa do discurso de guerra e a efetivação de uma política belicista contra o uso de psicoativos considerados ilícitos, que atendeu, inclusive aos auspícios da opinião pública (RODRIGUES, 2002; DUARTE; DALBOSCO, 2017).

Segundo Borges (2018), a lógica de tolerância zero que emerge com a guerra às drogas processa a união entre a premissa da abstinência e a ideia de segurança. Um truque de prestidigitação que muda o foco da questão social para a segurança pública. A manobra de deslocamento encobre o complexo das relações de desigualdade racial, social etc., para centrar todos os recursos nos "efeitos nocivos da droga".

Em nosso entendimento, esse discurso é o maior entorpecente a que estamos expostos, porque não há droga tão persuasiva e viciante quanto a ideologia dominante, que conjuga racismo e proibicionismo, justamente, porque reduz processos histórico-sociais e a dinâmica entre sociedade e Estado a um mero produto. A mercadoria "droga ilícita", fetichizada, caracterizada de dominante toma as rédeas das relações sociais. Opera-se então a inversão e todos terminamos adictos, nas palavras de Carl Hart (2015), são "slogans vazios para problemas reais".

É neste quadro que articula os elementos fundantes da modernidade ocidental, as questões estruturais da formação social brasileira e as dinâmicas dos processos econômicos e políticos no pósabolição que podemos compreender a racialização presente na Lei no $11.343 / 2006^{9}$ que promoveu a distinção entre traficante e usuário, uma alteração supostamente progressista e protetiva.

A nova lei que substituiu uma norma de 1976 também diferiu os crimes: a posse para uso pessoal virou um delito de ínfimo poten-

\footnotetext{
${ }^{9}$ Institui o Sistema Nacional de Políticas Públicas sobre Drogas - SISNAD; prescreve medidas para prevenção do uso indevido, atenção e reinserção social de usuários e dependentes de drogas; estabelece normas para repressão à produção não autorizada e ao tráfico ilícito de drogas; define crimes e dá outras providências.
} 
cial ofensivo com previsão de advertência e penas alternativas à prisão e o tráfico de drogas teve a pena mínima aumentada de três para cinco anos, podendo chegar a 15 anos de detenção. (BOITEUX, 2006)

A Lei qualifica o que é considerado tráfico e uso pessoal a partir das seguintes circunstâncias:

$\S 2$ o Para determinar se a droga destinava-se a consumo pessoal, o juiz atenderá à natureza e à quantidade da substância apreendida, ao local e às condições em que se desenvolveu a ação, às circunstâncias sociais e pessoais, bem como à conduta e aos antecedentes do agente (BRASIL, 2006).

O reconhecimento do racismo estrutural e do sistema antinegro nos permitem compreender sobre quem recaiu a imagem de traficante, justamente porque é a discriminação que guia o próprio inciso e embora a cor da pele não apareça como evidência ela determina a seleção das identidades de usuário e traficante (CARVALHO, 2015). Um outro fator determinante é que a legislação não traz uma definição precisa sobre o que é o uso e o que é o tráfico de drogas colaborando para uma aplicação aparentemente disfuncional da norma.

O Artigo 33 que trata do tráfico coloca como uma das condutas punidas a cessão gratuita de drogas de uma pessoa a outra. Isso não é tráfico, o tráfico envolve lucro. Outra coisa é que não se exige prova. A pessoa flagrada com determinada quantidade é presumida como traficante. Isso é inaceitável, porque o que se espera é que o Estado prove que aquela pessoa, de fato, trafica drogas, por meio, por exemplo, do extrato bancário ou por meio de uma investigação, com testemunhas etc. Nada disso é exigido, como regra, para uma pessoa ser condenada por tráfico (AGÊNCIA BRASIL, 2018)

Assim, a legislação tem funcionado na reprodução social da tipificação negro bandido e branco inocente. A bifurcação mantém-se: encarceramento e morte para os negros (traficantes) e atendimento em saúde para os brancos (usuários).

A aparente disfuncionalidade é identificada pelo fato de as resultantes da lei serem diferentes dos objetivos externados quando de sua publicação: proteger as pessoas usuárias de substâncias ilícitas. No entanto, o sistema funciona exatamente do modo como deveria 
em nossa sociedade, ou seja, protegendo quem merece ser protegido e punindo os "outros". A ausência de regras nítidas, esse "esquecimento", sintomático nas instituições brasileiras, permite que quem faça a distinção, nas ruas, sejam os próprios policiais. Por conseguinte, entendemos que o racismo não opera somente na batida policial, mas no processo institucional como um todo, desde a concepção da lei até a condenação e o encarceramento. Para a juventude negra, pobre e favelada as margens de dúvida são mínimas.

De maneira geral, quem está sendo preso no dia a dia é o jovem negro. Se a polícia pega um menino branco, que é um estudante universitário, frequenta uma universidade privada e está em seu veículo próprio, mesmo se estiver portanto uma quantidade grande de drogas, ele não vai ser considerado um traficante porque a reflexão imediata que o policial faz é: "esse cara não precisa traficar". Enquanto um menino negro, da favela, pego na rua, não importa que justificativa ele der para estar portando aquela quantidade de droga, ele vai sempre ser considerado um traficante (AGÊNCIA BRASIL, 2018).

A imagem ${ }^{10}$ a seguir, que constava em 2008 na apostila de uma disciplina obrigatória no curso de formação da polícia civil é emblemática da intrínseca relação entre racismo e criminalização negra no Brasil.

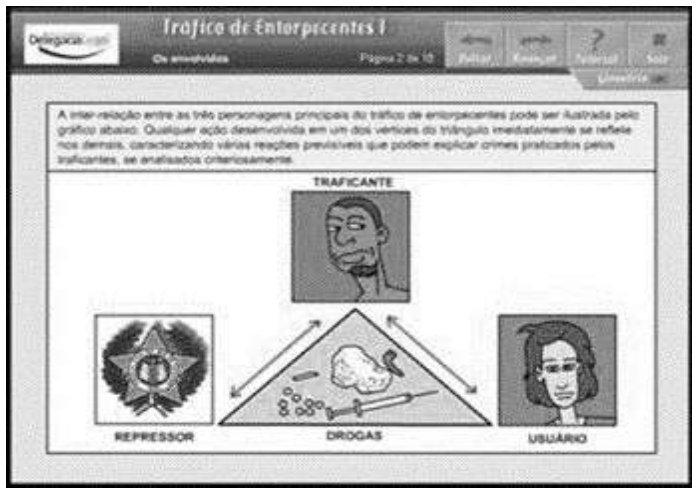

\footnotetext{
${ }^{10}$ Ilustração usada em um curso de atualização para policiais das Delegacias Legais, no ano de 2008. O curso, obrigatório para todos os policiais civis lotados nas Delegacias Legais ensinava a diferenciar o usuário de entorpecentes de um traficante (Jornal Extra, 22/09/2008, p. 8. Curso para policiais ensina que traficante é negro e usuário é branco). Disponível em < http://extra.globo.com/casos-de-policia/cursos-feitos-pela-delegacia-legal-para-policiaiscivis-nao-sao-unanimidade-579351.html>. Acesso em 12 set.2020.
} 
Fonte: Curso de atualização para policiais das Delegacias Legais no ano de 2008

Esta ilustração é de muitas maneiras a síntese definidora da cisão racializada entre usuário e traficante. A ideia da droga e dos negros como razões da violência urbana, não configura um padrão novo, uma vez que, a estes últimos já considerados "droga" passou a caber também a tipificação de traficante, materializando uma guerra cujas formas e resultantes tem sido cada vez mais chocantes para as vidas negras (HART, 2015).

O Brasil possui a terceira maior população carcerária do mundo, que contabiliza $773,151^{11}$ de presos, ou seja, quase um milhão de pessoas encarceradas. Consoante a isso, dois em cada três presos no Brasil é negro, um dado quantificado do encarceramento racializado que é também um dos efeitos da guerra às drogas (BORGES, 2018). $E$ o que possivelmente não nos coloca em primeiro lugar é o número de homicídios impetrados contra negros, sendo a maior parte deles, justificados no contexto da guerra às drogas.

Em 2017, 75,5\% das vítimas de homicídios foram indivíduos negros, ainda sendo que a taxa de homicídios por 100 mil negros foi de 43,1, ao passo que a taxa de não negros (brancos, amarelos e indígenas) foi de 16,0. [... Analisando apenas a variação no último ano, enquanto a taxa de mortes de não negros apresentou relativa estabilidade, com redução de 0,3\%, a de negros cresceu 7,2\% (CERQUEIRA et. al., 2019, p. 49).

A guerra às drogas é acima de tudo uma guerra racial, não existe destruição de drogas, existe a destruição de pessoas consideradas drogas. Vivemos o que nas palavras de Fanon (2008) é o círculo infernal onde ser negro é não ser humano, consumido por outros que reivindicam o lugar de humanidade. As díades escravo-pecado/negro-crime, são um continuum, as formas mudam, porém, os resultados ao final não são tão distintos.

A dinâmica de superampliação do encarceramento e morte, a partir da promulgação da Lei, surpreendeu somente aqueles que não acreditam na antinegritude e no racismo estrutural como balizadores das relações institucionais no país. Um exemplo dramático, que

\footnotetext{
${ }^{11}$ Dados extraídos da União, referentes ao ano de 2019, disponível em: <https://www.gov. $\mathrm{br} / \mathrm{pt}$-br/noticias/justica-e-seguranca/2020/02/dados-sobre-populacao-carceraria-do-brasilsao-atualizados>. Acesso em 12 set. 2020.
} 
expõe a cadeia constitutiva negro $=$ criminoso $=$ encarceramento e ou morte e resume o que vimos tratando neste ensaio, é o caso de Lucas Moraes Trindade, jovem negro, sem antecedentes criminais, sentenciado a 5 anos e 4 meses de reclusão, em 2018, por portar 10 gramas de maconha. Enquadrado como traficante teve dois habeas corpus negados, morreu na prisão vitimado pela COVID-19 (RIBEIRO, 2020).

\section{Considerações finais}

O longo percurso sóciohistórico de associação do negro primeiro ao pecado e depois ao crime é uma das chaves para a compreensão da invisibilização dos processos genocidas antinegro que estruturam a sociedade e o Estado brasileiro desde as suas origens. E um elemento reflexivo e antirracista de contraposição à banalização dos dados que explicitam o absurdo quantitativo de mortes negras por causas evitáveis, principalmente de jovens.

Um dos maiores feitos da "guerra às drogas" está em associar a um outro, que já possuía o estigma de criminoso, o lugar de traficante. A "guerra às drogas" não inventa nem a antinegritude e nem o racismo estrutural, mas é uma resultante, e ao mesmo tempo, uma estratégia de perpetuação dessas construções.

Ademais sedimentou um símbolo supostamente diferencial dentro do próprio grupo negro. A ilusão de que os "negros alinhados", cumpridores das normas estariam livres em contraposição aqueles "outros negros", "bandidos", merecedores das violências. Dessa forma as mortes por "equívoco", "balas perdidas", "prisões por engano" "execuções acidentais" etc. são danos colaterais da guerra. Independente das condutas as balas são racializadas e a diferenciação mostra-se muito mais como uma estratégia antiga e bem-sucedida de guerra: dividir para conquistar.

Contudo há vozes dissonantes, a Iniciativa Negra por uma Nova Política sobre Drogas, organização da sociedade civil, atua desde 2015 pela construção de uma agenda de justiça racial e econômica promovendo ações em direitos humanos e propondo reformas na atual política de combate às drogas. Um movimento que nos dá provas de que há luta, e que embora árdua, não está perdida e que o 
contraponto a guerras as "drogas" só pode ser capitaneado por aqueles que direta ou indiretamente são os mais atingidos.

\section{Referências}

ALMEIDA, S. de. $\mathbf{O}$ que é racismo estrutural? Belo Horizonte: Letramento, 2018.

ANDREWS, G. R. Negros e brancos em São Paulo (1888-1988). Florianópolis: EDUSC, 1998.

APÓS quase dez anos, Lei de Drogas aumentou número de pessoas encarceradas. Agência Brasil, São Paulo, 23 de set. de 2006. Disponível em: <https://agenciabrasil.ebc.com.br/geral/noticia/2016-09/ apos-quase-dez-anos-lei-de-drogas-aumentou-numero-de-pessoasencarceradas>. Acesso em: 20 set. 2020.

BOITEUX, L. A Nova Lei Antidrogas e o aumento da pena do delito de tráfico de entorpecentes. Boletim IBCCrim, São Paulo, v. 14, n. 167, p. 8-9, out., 2006.

BORGES, E.; D'ADESKY, J.; MEDEIROS, C. A. Racismo, preconceito e intolerância. São Paulo: Atual, 2002.

BORGES, J. Encarceramento em massa. Belo Horizonte: Letramento; Justificando, 2018.

BRASIL. Lei no 11.343, de 23 de agosto de 2006. Brasília: Diário Oficial da União, 24 de agosto de 2006, p. 2. Disponível em: < http:// www.planalto.gov.br/ccivil_03/_ato20042006/2006/lei/

I11343.htm\#: :text=Institui\%200\%20Sistema\%20Nacional\%20de,crimes\%20e\%20d\%C3\%A1\%20outras\%20provid\%C3\%AAncias >. Acesso em: 13 set. 2020.

CARNEIRO, A. S. A construção do outro como não-ser como fundamento do ser. 339f. Tese (Doutorado em Educação) - Faculdade de Educação, Universidade de São Paulo, São Paulo, 2005.

CARNEIRO, H. As necessidades humanas e o proibicionismo das drogas no século XX. Revista Outubro, São Paulo, v. 6, n. 6, p. 115-128, 2002. 
CARVALHO, S. de. O encarceramento seletivo da juventude negra brasileira: a decisiva contribuição do Poder Judiciário. Revista da Faculdade de Direito da UFMG, n. 67, p. 623-652, 2015.

CERQUEIRA, D. et al. (Coord.). Atlas da violência 2019: retrato dos municípios brasileiros. Rio de Janeiro: IPEA, julho de 2019.

DUARTE, P. do C. A. V.; DALBOSCO, C. A política e a legislação brasileira sobre drogas. DUARTE, P. do C. A. V.; FORMIGONI, M. L. O. de S. (Org.). O uso de substâncias psicoativas no Brasil: módulo 1, cap. 6, p. 113-126, SUPERA. 11aㅡ ed. Brasília: SENAD, 2017.

DUSSEL, E. 1492: o encobrimento do outro - a origem do mito da modernidade; Conferências de Frankfurt. Petrópolis: Vozes, 1993.

FANON, F. Pele negra, máscaras brancas. Salvador: EDUFBA, 2008. FERRUGEM, D. Guerra às drogas e a manutenção da hierarquia racial. São Paulo: Letramento, 2019.

HART, C. L. Slogans vazios, problemas reais. Revista Sur - Revista Internacional de Direitos Humanos, São Paulo, v. 12, n. 21, ago., 2015.

HENMAN, A. R. A guerra às drogas é uma guerra etnocida: um estudo do uso da maconha entre os índios Tenetehara do Maranhão. Religião e Sociedade, Rio de Janeiro, n.10, p. 37- 48, 1983.

KILOMBA, G. Memórias da plantação: episódios de racismo cotidiano. Rio de Janeiro: Cobogó, 2019.

LEI de drogas tem impulsionado encarceramento no Brasil. Agência Brasil, Brasília, 24 de jun. de 2018. Disponível em: <https://agenciabrasil.ebc.com.br/geral/noticia/2018-06/lei-de-drogas-tem-impulsionado-encarceramento-no-brasil>. Acesso em: 20 set. 2020.

LEMOS, C. A outra história da guerra às drogas: contribuições da oitava tese de Walter Benjamin. Passagens - Revista Internacional de História Política e Cultura Jurídica, Niterói, v. 7, n. 3, p. 556-581, set./ dez., 2015.

LUNARDON, J. A. Maconha, capoeira e samba: a construção do proibicionismo como uma política de criminalização social. Porto Alegre, 
Porto Alegre: I Seminário Internacional de Ciência Política, da Universidade Federal do Rio Grande do Sul, setembro, 2015.

MBEMBE, A. Critica a razão negra. São Paulo: N-1 edições, 2018.

MOURA, C. Rebeliões da senzala: quilombos, insurreições, guerrilhas. 4. ed. Porto Alegre: Mercado Aberto, 1988.

OLIVA, A. R. Lições sobre a África: diálogos entre as representações dos africanos no imaginário ocidental e o ensino da história da África no mundo Atlântico (1990-2005).2007. Tese (Doutorado em História Social). Instituto de Ciência Humanas. Universidade de Brasília, 2007.

QUIJANO, A. Colonialidade do poder, eurocentrismo e América Latina. In: LANDER, E. (Org.). A colonialidade do saber, eurocentrismo e Ciências Sociais: Perspectivas latinoamericanas. Ciudad Autónoma de Buenos Aires: CLACSO, setembro, 2005. Disponível em: < http://biblioteca.clacso.edu.ar/ar/libros/lander/pt/lander.html>. Acesso em: 07 set. 2020.

RIBEIRO, D. Negro é traficante, branco é estudante que faz 'delivery de drogas'. Folha de São Paulo, São Paulo, 19 de jul. 2020. Disponível em:< https://www.geledes.org.br/negro-e-traficante-branco-e-estudanteque-faz-delivery-dedrogas/?gclid=CjOKCQjwnqH7BRDdARIsACTSAdtZgkXsQKcMh3uTejVKTd5Xc75cFHNDkcJB2aF6UjzXBh2wiqbetAUaAg_EALw_wcB>. Acesso em: 20 ago. 2020.

RODRIGUES, T. A infindável guerra americana: Brasil, EUA e o narcotráfico no continente. São Paulo em perspectiva, v. 16, n. 2, p. 102111, 2002.

SAAD, L. "Fumo de negro": a criminalização da maconha no pós-abolição. Salvador: EDUFBA, 2018.

SCHWARCZ, L. M. O espetáculo das raças: cientistas, instituições e questão racial no Brasil. São Paulo: Companhia das Letras, 1993.

WAISELFISZ, J. J. Mapa da violência 2016: homicídios por armas de fogo. Brasília: Secretaria Nacional de Juventude; FLACSO Brasil, 2016. 